\title{
Anthropometric Considerations for Hand Tool/Machinery Design for Chhattisgarh Female Workers of Raipur Districts, India
}

\author{
Priya Sinha* and S. V. Jogdand \\ Department of FMPE, SVCEAT \& RS, FAE, IGKV, Raipur (C.G.), India \\ *Corresponding author
}

\section{A B S T R A C T}

Keywords

Ergonomic, Tool, Anthropometric,

Female

Article Info

Accepted:

04 October 2019

Available Online:

10 November 2019
Anthropometric data of agricultural farm women is very essential for appropriate and efficient designing of farm machinery. This study revealed that anthropometric measurements of Chhattisgarh female farmers. The minimum, mean, and the maximum stature values are 146.3, 159.0, 174.6 $\mathrm{cm}$ for Female farmers respectively. The data was further analyzed and the efforts had been made to illustrate the applications of these measurements for designing and standardization of women friendly equipment. In the study, in addition to the descriptive values, 5th, 50th and 95th percentile values were also calculated.

\section{Introduction}

Chhattisgarh has 7.48 million ha land under cultivation out of which 38.16 lakh ha land is under rice cultivation with rice production of about 57.89 lakh tonnes and with the productivity $1517 \mathrm{~kg} / \mathrm{ha}$ during the year 2015 16 (Anonymous, 2016). Women do the most tedious and back-breaking tasks in agriculture, animal husbandry and at homes. Their contribution is very high in farm sector as they are involved in most of the farm operations and are, therefore, subjected to extra harsh conditions of work that lead to drudgery. Anthropometric dimensions vary considerably across gender, race and age. Within a particular group also the anthropometry differs due to nutritional status and nature of work.

Thus to achieve better performance and efficiency along with higher comfort and safety to the operator, it is necessary to design tools, equipments and workplaces keeping in view of the anthropometric data of the agricultural workers.

It is very much essential for the designer to consider physical dimensions and human capabilities while designing farm equipments for better output and safety, because the manmachine interface decides the ultimate performance of the equipment. 


\section{Materials and Methods}

\section{Measurement of body dimensions}

Anthropometric measurements were carried out on 30 female of different age group of Raipur district randomly chosen among hand hoe, hand operated paddy weeder, manually operated harvester, agricultural farm labours only. The age of the selected subjects varied from 22 to 50 years. Twenty seven measurements included bodyweight, stature, chest circumference, arm length, buttock political length, hip breadth (standing) etc. were selected from a farm machinery design point of view. The observations were taken carefully to measure all the dimensions in a correct posture and precise manner. Standing height (stature), bodyweight, hip breadth, etc. were measured in standing posture for that the subjects were asked to stand on a flat surface; their arms were adjusted according to their height, with their feet closed and their body vertically erected, while their heels, buttocks and shoulders touched the same vertical plane. The measurements were recorded from the vertical scale. An anthropological instrument (anthrop meter) was used for taking measurements with an accuracy of $\pm 0.25 \mathrm{~mm}$.

Table 1, 2 and 3 gives anthropometric data of Chhattisgarh regions female farm workers, for the various body dimensions, which were considered to be useful in farm machinery design. Their respective estimates of mean, standard deviation, and coefficient of variation are also presented. The coefficient of variation is found maximum for the body weight.

The data were also analyzed for percentile distributions (5th, 50th and 95th) are presented in Table 1, 2 and 3. For design purpose, either one of the boundary values or the mean value is used. For boundary 5 th and $95^{\text {th }}$ percentile values are used and 5th percentile values would be used for design it will also take care of $95 \%$ of the population. Thus, overall $90 \%$ of the population is taken into account and the $10 \%$ skipped population outside these boundaries were not take into account as they offer uneconomical.

\section{Criteria for ergonomic design}

Design within the capability of a human worker.

Use of proper posture of the operator for most efficient performance of the tool at a lesser fatigue.

Suitability of the tool for workers of varying age and body dimensions.

\section{Result and Discussion}

\section{Anthropometric data of female farm labours}

The anthropometric data of three age groups of 30 female labour for the various body dimensions and the estimates of mean, standard deviation, coefficient of variation and percentile values $\left(5^{\text {th }}, 50^{\text {th }}\right.$ and $\left.95^{\text {th }}\right)$ are presented in table 1,2 and 3 of different body dimensions and hand dimensions. The anthropometric data is taken as a guideline in designing the proper handle height, grip diameter, length of handles for getting more human comfort and better operational efficiency.

Table 1, 2 and 3 shows the percentile values of mean of three different age group (22-32, 3242 and 42-50 years) of female workers for designing of hand tool machinery. Mainly shoulder height and elbow height were taken into consideration. Statistical data shows that variation among the females labour regarding these two parameters was very less. Hence mean value of shoulder height and elbow height 118.71, 123.06, 130.85 and 85.55, 
93.68, 109.67 for $5^{\text {th }}, 50^{\text {th }}$, and $95^{\text {th }}$ percentile female workers of age group 22-50 were considered.

Percentile values of hand dimensions of female workers are presented in table 1,2 and 3 hand dimensions are important for design of handle dimensions of the machine. Proper grip is required for effective force application while working with these tools. The $5^{\text {th }}, 50^{\text {th }}$ and $95^{\text {th }}$ percentile values of grip diameter (inside) of female workers of Chhattisgarh Raipur were found as $2.42,3.1$ and $4.10 \mathrm{~cm}$ respectively. For a comfortable holding of the grip, the grip needs to be designed in such a way that a person with $5^{\text {th }}$ percentile body dimensions $2.5 \mathrm{~cm}$ able to properly grip the handle. Therefore, the minimum diameter of the grip should be for tool being operated by the female workers. Since variation among different labours was

This survey work set out to assist the development of more appropriately designed equipments, tools and agricultural machinery. The anthropometric survey was carried out on rural population in this respect to provide the better designed and modified agricultural equipments, tools and machinery by designers suiting to the human capabilities by using this survey data as a guide line for Chhattisgarh region (Fig. 1).

Table.1 Percentile values of different body dimensions of female workers age group (22-32)

\begin{tabular}{|c|c|c|c|c|c|c|c|c|}
\hline Parameters & Mean & Min & Max & $5^{\text {th }}$ & $50^{\text {th }}$ & $95^{\text {th }}$ & SD & $\mathrm{CV}$ \\
\hline Age (year) & 28.3 & 22 & 32 & 22.4 & 29 & 32 & 3.65 & 0.12 \\
\hline Weight (kg) & 44.4 & 37 & 56 & 37.4 & 44 & 53.3 & 5.96 & 0.13 \\
\hline Stature & 150.1 & 146 & 157 & 146.4 & 150 & 155.65 & 3.31 & 0.02 \\
\hline Eye height & 138.7 & 133.6 & 143 & 133.7 & 140 & 141.74 & 2.90 & 0.02 \\
\hline Shoulder & 123.8 & 119 & 134 & 119 & 122.6 & 132.2 & 4.70 & 0.03 \\
\hline Elbow height & 97.1 & 83 & 119 & 86.1 & 94 & 114.95 & 10.6 & 0.10 \\
\hline Hip height & 88.3 & 83 & 92 & 83.9 & 89.2 & 91.1 & 2.68 & 0.03 \\
\hline Knuckle height & 80.4 & 75 & 86 & 75 & 83 & 85.55 & 4.71 & 0.05 \\
\hline Knee height & 44.1 & 39 & 47 & 40.0 & 45 & 46.55 & 2.39 & 0.05 \\
\hline $\begin{array}{l}\text { Waist back } \\
\text { length }\end{array}$ & 31.9 & 27 & 42 & 27.09 & 30.5 & 41.1 & 5.20 & 0.16 \\
\hline $\begin{array}{l}\text { Forward arm } \\
\text { reach }\end{array}$ & 68.3 & 66 & 70 & 66.4 & 68 & 70 & 1.26 & 0.01 \\
\hline Hip breath & 32.3 & 24 & 43 & 25.3 & 30.9 & 40.3 & 5.62 & 0.17 \\
\hline $\begin{array}{c}\text { Buttock knee } \\
\text { height }\end{array}$ & 78.8 & 76 & 82 & 76.9 & 79 & 81.1 & 1.53 & 0.01 \\
\hline $\begin{array}{c}\text { Middle finger to } \\
\text { elbow }\end{array}$ & 42.2 & 38 & 44 & 38 & 43.7 & 44 & 2.55 & 0.06 \\
\hline Foot breath & 9.9 & 8.7 & 11 & 9.0 & 10 & 10.64 & 0.57 & 0.05 \\
\hline Foot length & 21.4 & 19 & 23.1 & 19.4 & 22 & 23.05 & 1.54 & 0.07 \\
\hline Hand length & 17.9 & 15 & 20 & 15.9 & 18 & 19.5 & 1.4 & 0.08 \\
\hline $\begin{array}{l}\text { Hand breadth } \\
\text { at thumb }\end{array}$ & 9.4 & 8 & 10.1 & 8.45 & 9.5 & 10.0 & 0.64 & 0.06 \\
\hline $\begin{array}{l}\text { Grip diameter } \\
\text { (inside) }\end{array}$ & 3.4 & 2.5 & 4.5 & 2.5 & 3.2 & 4.2 & 0.69 & 0.20 \\
\hline
\end{tabular}

All the dimensions are in $\mathrm{cm}$, unless specified. 
Table.2 Percentile values of different body dimensions of female workers Age group (33-42)

\begin{tabular}{|c|c|c|c|c|c|c|c|c|}
\hline Parameters & Mean & Min & Max & $\mathbf{5}^{\text {th }}$ & $\mathbf{5 0}^{\text {th }}$ & $\mathbf{9 5}^{\text {th }}$ & SD & CV \\
\hline Age (year) & 37.8 & 33 & 42 & 33.9 & 38 & 41.55 & 2.74 & 0.07 \\
\hline Weight (kg) & 45.2 & 36 & 59 & 37.35 & 45.5 & 54.95 & 6.44 & 0.14 \\
\hline Stature & 149.22 & 140 & 156 & 142.25 & 149.1 & 155.55 & 4.72 & 0.03 \\
\hline Eye height & 139.48 & 133 & 145.8 & 133 & 140.5 & 145.44 & 5.01 & 0.03 \\
\hline Shoulder & 124.5 & 115 & 130 & 118.15 & 124 & 130 & 4.52 & 0.03 \\
\hline Elbow height & 94.52 & 83 & 99.2 & 85.25 & 96 & 99.11 & 5.41 & 0.05 \\
\hline Hip height & 86.42 & 82 & 90.2 & 82.9 & 86 & 90.11 & 2.70 & 0.03 \\
\hline Knuckle height & 77.9 & 73 & 83 & 74.35 & 77.5 & 83 & 3.14 & 0.04 \\
\hline Knee height & 43.42 & 32 & 51 & 35.6 & 44 & 50.1 & 5.38 & 0.12 \\
\hline Waist back length & 43.2 & 30 & 51 & 34.27 & 44.3 & 49.78 & 5.66 & 0.13 \\
\hline Forward arm reach & 66.92 & 58 & 70 & 61.69 & 68 & 69.55 & 3.30 & 0.04 \\
\hline Hip breath & 30.71 & 22 & 36 & 23.8 & 31.4 & 35.46 & 4.27 & 0.13 \\
\hline Buttock knee height & 78.32 & 70.2 & 83.5 & 72.63 & 79.25 & 82.82 & 3.82 & 0.04 \\
\hline Middle finger to elbow & 41.05 & 33.5 & 45.3 & 35.52 & 41.5 & 45.16 & 3.63 & 0.08 \\
\hline Foot breath & 25.64 & 23 & 27 & 23.8 & 25.4 & 27 & 1.29 & 0.05 \\
\hline Foot length & 8.21 & 6.4 & 10 & 6.44 & 8.25 & 10 & 1.62 & 0.19 \\
\hline Hand length & 17.9 & 16 & 19.5 & 16.45 & 18.05 & 19.27 & 1.09 & 0.06 \\
\hline Hand breadth at thumb & 9.16 & 8.2 & 9.7 & 8.56 & 9.2 & 9.61 & 0.40 & 0.04 \\
\hline Grip diameter (inside) & 3.04 & 2.1 & 3.7 & 2.28 & 3.1 & 3.61 & 0.49 & 0.16 \\
\hline Albianty
\end{tabular}

All the dimensions are in $\mathrm{cm}$, unless specified.

Fig.1
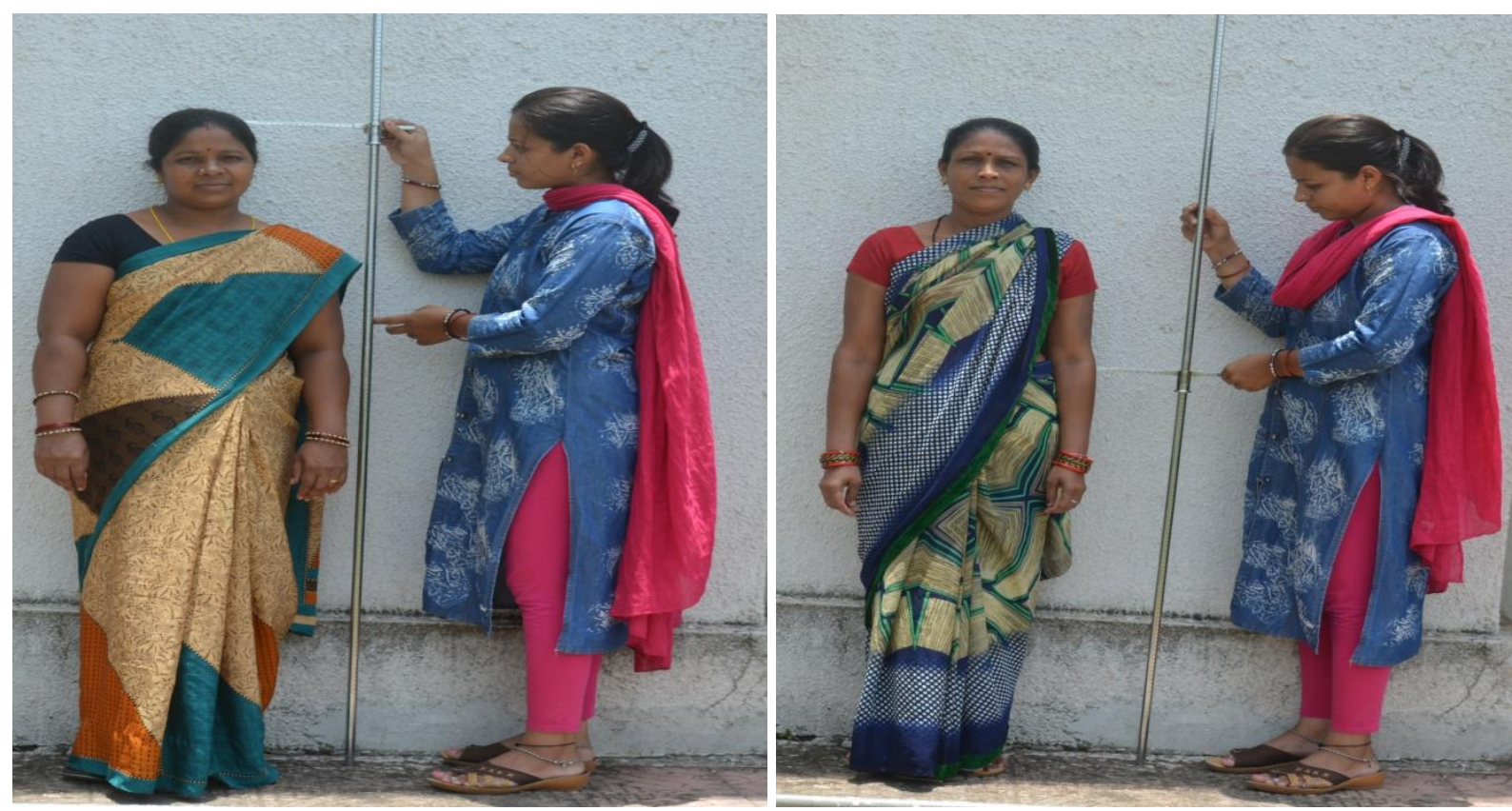
Table.3 Percentile values of different body dimensions of female workers Age group (43-50)

\begin{tabular}{|c|c|c|c|c|c|c|c|c|}
\hline Parameters & Mean & Min & Max & $\mathbf{5}^{\text {th }}$ & $\mathbf{5 0}^{\text {th }}$ & $\mathbf{9 5}^{\text {th }}$ & SD & CV \\
\hline Age (year) & 48 & 45 & 50 & 45 & 49 & 50 & 2.26 & 0.04 \\
\hline Weight (kg) & 51.7 & 39 & 67 & 41.7 & 51.5 & 63.85 & 8.15 & 0.15 \\
\hline Stature & 148.51 & 143 & 159 & 143 & 147.4 & 156.75 & 5.28 & 0.03 \\
\hline Eye height & 137.67 & 129 & 146 & 129.45 & 138 & 145.82 & 6.70 & 0.04 \\
\hline Shoulder & 123.14 & 119 & 130 & 119 & 122.6 & 128.65 & 4.08 & 0.03 \\
\hline Elbow height & 94.78 & 85.3 & 119 & 85.3 & 91.05 & 114.95 & 11.18 & 0.11 \\
\hline Hip height & 86.87 & 80 & 97.2 & 81.35 & 85.15 & 95.31 & 5.21 & 0.06 \\
\hline Knuckle height & 77.59 & 70.2 & 89.4 & 70.56 & 74.75 & 87.51 & 7.11 & 0.09 \\
\hline Knee height & 43 & 38 & 48 & 38 & 42.15 & 47.415 & 3.41 & 0.07 \\
\hline Waist back length & 41.76 & 30 & 45.5 & 34.5 & 42.75 & 45.32 & 4.60 & 0.11 \\
\hline Forward arm reach & 71 & 68 & 78.2 & 68 & 69.85 & 76.85 & 3.37 & 0.04 \\
\hline Hip breath & 32.36 & 27.6 & 39 & 28.23 & 32.5 & 38.1 & 3.77 & 0.11 \\
\hline Buttock knee height & 78.98 & 76 & 83 & 76.045 & 79 & 82.55 & 2.42 & 0.03 \\
\hline Middle finger to elbow & 44.36 & 42 & 50.1 & 42 & 43.65 & 48.34 & 2.57 & 0.05 \\
\hline Foot breath & 34 & 28 & 41 & 28.45 & 34 & 40.1 & 4.16 & 0.12 \\
\hline Foot length & 9.2 & 7.5 & 13 & 7.63 & 8.85 & 11.65 & 1.60 & 0.17 \\
\hline Hand length & 17.5 & 15 & 20 & 15.67 & 17.45 & 19.55 & 1.46 & 0.08 \\
\hline Hand breadth at thumb & 9.09 & 8 & 10 & 8.22 & 9.1 & 10 & 0.63 & 0.07 \\
\hline Grip diameter (inside) & 3.3 & 2.5 & 4.5 & 2.5 & 3.1 & 4.5 & 0.79 & 0.23 \\
\hline Alb
\end{tabular}

All the dimensions are in $\mathrm{cm}$, unless specified.

\section{References}

Agrawal N.K., Singh P.K.R. and K. K. Satapathy K.K. (2010) Anthropometric Considerations for Farm Tools/Machinery Design for Tribal Workers of North Eastern India. Agricultural Engineering International: the CIGR Ejournal. Manuscript MES 1406 Vol. XII. March.

Mishra Reeta, Singh P. Y., Mishra D. Y., Singh Swati and Singh Harvendra (2013). Dissemination of Improved Sickles for Female Agriculture Workers for Crop Harvesting Journal of Multidisciplinary Advance Research Vol.2 No. 1, 118-123 (2013).

Singh Alka, Gautam U. S., Singh Rajesh and Paliwal Dinesh (2014). Ergonomic study of farm women during wheat harvesting by improved sickle, African
Journal of Agricultural Research Vol. 9 (18), pp. 1386-1390, 1 May, 2014.

Singh, R.; Khakha, J. and Singh, G. (2009). Development and testing of manually operated vertical conveyor reaper. Unpublished, B-Tech. Dissertation, submitted to Indira Gandhi Agricultural University, Raipur.

Victor Viren M., Saswati Nath, AjayVerma (2002) Anthropometric survey of Indian farm workers to approach ergonomics in agricultural machinery design Applied Ergonomics 33 (2002) 579-581.

Verma, S., Gupta, S. and Pachauri, C.P. (2016). Superiority of the Naveen serrated sickle over the traditional sickle for wheat harvesting. International Journal of Farm Sciences, 6(1): 214-222. 


\section{How to cite this article:}

Priya Sinha and Jogdand, S. V. 2019. Anthropometric Considerations for Hand Tool/Machinery Design for Chhattisgarh Female Workers of Raipur Districts, India. Int.J.Curr.Microbiol.App.Sci. 8(11): 92-97. doi: https://doi.org/10.20546/ijcmas.2019.811.011 